\title{
'Open Price' Term under the United Kingdom Sale of Goods Act 1979 and the United Nations Convention on Contracts for International Sale of Goods (CISG): A Comparative Analysis
}

\author{
Farzaneh Akrami ${ }^{1}$, Sakina Shaik Ahmad Yusoff ${ }^{1} \&$ Suzanna Mohamed Isa $^{1}$ \\ ${ }^{1}$ Faculty of Law Universiti Kebangsaan Malaysia, Bangi, Selangor, Malaysia \\ Correspondence: Sakina Shaik Ahmad Yusoff, Faculty of Law, Universiti Kebangsaan Malaysia, Bangi, \\ Selangor, Malaysia. Tel: 60-19-273-5798. E-mail: kinasay@ukm.my
}

Received: May 8, 2014 Accepted: June 3, 2014 Online Published: July 11, 2014

doi:10.5539/ass.v10n15p97

URL: http://dx.doi.org/10.5539/ass.v10n15p97

\begin{abstract}
Sections 8 and 9 of the Sale of Goods Act of United Kingdom (SGA 1979) and Article 55 of the United Nations Convention on Contracts for International Sale of Goods (CISG) provide the rules on open price term in contracts for the sale of goods. The concept of open price was created following new circumstances in the global trade, necessities and needs of humankind. However, changes in the rules should be compatible with these new needs. Good rules are those that not only have been initially formed and drafted in a wise and precise manner, but also have been amended based on the shortcomings that it may have in practice. Otherwise, it would be a repetition of negligence of legislators each time that a weak, un-amended rule is performed. Since the enactment of the SGA 1979, which is a copy of its preceding provisions in SGA 1893, it has not reviewed or amended. This is the same with the provisions of the CISG. Thus, in this paper, through a doctrinal type of research and a comparative, analytical and critical approach to the issue, a library based study has been performed on SGA 1979 and the CISG. The aim of this paper is to highlight the salient aspects of the open price provisions in SGA 1979 and CISG in order to propose the necessity of their amendment.
\end{abstract}

Keywords: open price term, contract of sale of goods, UK sale of goods act (1979), United Nations convention on Contracts for International Sale of Goods (CISG)

\section{Introduction}

Prosser (1932) noted that the most important function of an open price term in a sale contract is to shift the risk caused by a fluctuating market from one of the parties to the other. The seller may want to avoid any risk and at the same time be assured of a market for his product either immediately or in the future. The buyer may also want to be assured of the supply of goods while there is always the possibility of a decline in price. In cases where the delivery is supposed to be performed at a future date, the parties may be uncertain about what the future price of the goods will be. In view of these conditions, there were attempts to deal with the transfer of risks in a changing and fluctuating market between the parties. Ultimately, this "has led to a variety of business arrangements by which, in a sale contract, the price is left open for future determination." (Prosser, 1932)

Aside from what an open price term economically means, this phrase has also been described by legislations. However, although the task of law is to provide order in society, peace and justice, defective rules can play an opposite role. With regard to open price term, although some rules have accepted this concept, there are, however, shortcomings and defective provisions that may even add to the problems and need to be amended. The two legislations that are studied in this paper are the Sale of Goods Act (SGA) 1979 as a domestic rule and the United Nations Convention on Contracts for the International Sale of Goods (CISG) as an international set of rules. These two codifications have recognized open price term. However, are these codifications are comprehensive and helpful or they consist of certain shortcomings? The next question would be what the negative and positive points of each of them are and do they need to be amended? As such, this paper aims to review and manifest the existing inconsistencies and problems of 'open price term' under the SGA 1979 and in the CISG.

The CISG, according to Gabuardi (2004), is a tool of private international law that contains relevant rules for the international sale. Although in CLOUT case No. 201, Richteramt Laufen des Kantons Berne, Switzerland, 7 
May 1993, the court stated that the CISG is comprehensive and that it constitutes "an exhaustive body of rules," similar to other international uniform law conventions, Ferrari (1998) opines it does not cover all the necessary issues that may arise from international contracts. Indeed, some matters are still left unaddressed. As far as the CISG is concerned, this can easily be seen by looking at some of its Articles, one being Article 55 .

As for the SGA 1979, existence of an open price provision is a perfect sign of an evolution and transformation from traditional rule to a more flexible one. Commentators (Berry, 2007) believe that the concept of open price in modern transactions has marked a significant departure from the common law because in common law, price is a vital feature for all sale contracts. Therefore, under traditional common law, open price term contracts would have been invalidated as 'agreements to agree' and held not to be legally binding. Yet, such provisions are likely to be a base for debates and arguments and sections 8 and 9 of the SGA 1979 have been no exception. Thus, the fact that these sections have existed in SGA 1983 to date is a considerable issue.

To draft a comprehensive rule that does not cause contradictory interpretations is one of the most important concerns in drafting a provision. Rules that contain ambiguity or are not clear and comprehensive will result in debates and disputes. Hence, in considering Article 55 of the CISG and sections 8 and 9 of the SGA 1979, different aspects and matters that are missing, or are mentioned but may need to be amended will be studied in this paper. Below, the respective provisions in the SGA 1979 and the CISG are iterated.

Sections 8 and 9 of the SGA 1979 with the long title of "An Act to consolidate the law relating to the sale of goods' impose the same rules and have the same concept and idea as sections 8 and 9 of the former Sale of Goods Act 1893. Sections 8 and 9 of SGA 1979 stipulates that:

\section{8-Ascertainment of price}

(1)The price in a contract of sale may be fixed by the contract, or may be left to be fixed in a manner agreed by the contract, or may be determined by the course of dealing between the parties.

(2)Where the price is not determined as mentioned in sub-section (1) above the buyer must pay a reasonable price.

(3)What is a reasonable price is a question of fact dependent on the circumstances of each particular case.

9-Agreement to sell at valuation

(1) Where there is an agreement to sell goods on the terms that the price is to be fixed by the valuation of a third party, and he cannot or does not make the valuation, the agreement is avoided; but if the goods or any part of them have been delivered to and appropriated by the buyer he must pay a reasonable price for them.

(2) Where the third party is prevented from making the valuation by the fault of the seller or buyer, the party not at fault may maintain an action for damages against the party at fault.

Any legislation and a set of rules may have some negative points in it. SGA 1979 as a domestic rule has some noticeable points to be considered. However, what is less tolerable and acceptable by the needs and necessities of the world's trade is an international set of rules in which there is apparent conflict and debatable negative and vague points. Among the most important conventions on uniform commercial laws that are currently in force, the 1980 United Nations Convention on Contracts for the International Sale of Goods (CISG) certainly stands out, even if for diverse reasons (Ferrari, 1997). Until 2013, CISG has around eighty member states, with ninety percent of which are leading trade nations. It has been estimated that about seventy to eighty percent of all international sales transactions are potentially governed by the CISG (Schwenzer \& Hachem, 2009). CISG represents one of the most important attempts towards the creation of uniform law on international sales, although there have been other attempts as well (Ferrari, 1994). Since the enactment of CISG, there have been different texts written on it. Some criticized while others just praised (Eorsi, 1983). CISG is a tool for private international law that contains related rules for international sale of goods. Article 55 of the CISG in which the provisions on open price term are imposed is an Article that seems to have some shortcomings and what is more is the issue of its apparent conflict with Article 14 (1) of the same Convention in which the formation of the contract is mentioned (Gabuardi, 2004). Article 14 (1) reads:

(1) A proposal for concluding a contract addressed to one or more specific persons constitutes an offer if it is sufficiently definite and indicates the intention of the offer or to be bound in case of acceptance. A proposal is sufficiently definite if it indicates the goods and expressly or implicitly fixes or makes provision for determining the quantity and the price.

On the other hand, the provision in the Article 55 provides that: 
Where a contract has been validly concluded but does not expressly or implicitly fix or make provision for determining the price, the parties are considered, in the absence of any indication to the contrary, to have impliedly made reference to the price generally charged at the time of the conclusion of the contract for such goods sold under comparable circumstances in the trade concerned.

A precise study on these sections will reveal some significant points to be considered and perhaps to be amended. Thus, a doctrinal method with analytical, critical approach has been employed in which the needed data have been collected via a library-based data collection and research. In considering sections 8 and 9 of the SGA 1979 and Articles 55 and 14 of the CISG, the following are different aspects to be deliberated as these issues are contended to be relevant in an Article on open price term namely, the issue of circumstances under which the price is considered to be an 'open price', the valuation of the price by a third person, and the impossibility of price fixation due to fault of one party.

\section{Circumstances under Which the Price Is Considered to Be an 'Open Price'}

In Article 55 of CISG, it is stated that, "where a contract has been validly concluded but does not [emphasis added] expressly or implicitly fix or make provision for determining the price, the parties are considered ... to have impliedly made reference to the price ..." At this point, the question will be, if the parties have implicitly fixed, or made provision for the determination of the price, but later, due to some circumstances, it becomes impossible to fix the price, will such a case be also covered by Article 55? Will the parties still be 'considered to have impliedly made reference to the price', or will this situation fall outside the provision?

It should be pointed out that the problem identified in the CISG also exists in the SGA. The provision in section $8(2)$ of the SGA is "where the price is not determined as mentioned in sub-section (1) above, the buyer must pay a reasonable price." Similarly, in this codified set of rules, nothing is mentioned about cases where the parties have agreed on the special situations described in 'sub-section (1)', but due to some circumstances, it becomes impossible to determine the price in the manner agreed. This is the first shortcoming of this provision. In fact, when section 8 (2) expressly states that where the price is not fixed by the contract, or is not left to be fixed in a manner agreed by the contract, or is not determined by the course of dealing between the parties, then an open price will be specified for the contract. The question is in which part of this section have the legislators considered the situation in which the price in a contract of sale is left to be fixed in a manner agreed by the contract, or is to be determined by the course of dealing between the parties, however, later, it becomes impossible to fix the price? This lack of information in the section has caused contradictory opinions to be issued by the courts.

The important question to be considered is that "when section 8 says that the price can be 'left to be fixed in a manner agreed', does this exclude the possibility that 'the manner' may simply require the parties to agree on the price? (Atiyah, 2010)." As to this question, it has been suggested that in accordance with section 8 and its wording, an agreement to leave the price open to be negotiated in the future will exclude any possibility that the price should be a reasonable price. It is a new trend of the courts to uphold the bargains that the parties believe to have been concluded that causes such agreements to be considered as enforceable (Benjamin, 2010). With regard to section 8 of the SGA 1979, the failure to indicate whether the parties can leave the contractual price completely open, to be fixed through a future agreement, creates a possibility for disagreements, as well as conflicting judicial decisions.

The House of Lords' decision in May \& Butcher $v$ The King [1934] 2 KB 17n, was an agreement in which the parties had agreed to fix the price at a future time without mentioning any method for price determination was not a binding contract. In fact, the House of Lords refused to uphold the contract contrary to the clear intention of the parties to be bound by it. In this case, Lord Buckmaster ([1934] 2 KB 17n, p 20) stated that:

In my opinion there never was a concluded contract between the parties. It has long been a well-recognized principle of contract law that an agreement between two parties to enter into an agreement in which some critical part of the contract matter is left undetermined is no contract at all. It is of course perfectly possible for two people to contract that they will sign a document which contains all the relevant terms, but it is not open to them to agree that they will in the future agree upon a matter which is vital to the arrangement between them and has not yet been determined. In this case, Viscount Dunedin ([1934] 2 K.B. 17, p 21) states that: “...we are here dealing with sale, and undoubtedly price is one of the essentials of sale, and if it is left still to be agreed between the parties, then there is no contract."

It is also worthy to mention that in this case there are two different ideas on one issue showing the necessity of clarifying what the provisions in sections 8 and 9 are. Viscount Dunedin first states that: “...we are here dealing with sale, and undoubtedly price is one of the essentials of sale, and if it is left still to be agreed between the 
parties, then there is no contract..." and then he adds: “...there would have been a perfectly good settlement of price if the contract had said that it was to be settled by arbitration of a certain man or by..."

Viscount Dunedin believes that to appoint a third party (a certain man) to settle the price would alter the result. However, this is expressly in conflict with the reasoning of Lord Buckmaster ([1934] 2 K.B. 17n, 20), in the same case who states:

I find myself quite unable to understand the distinction between an agreement to permit the price to be fixed by a third party and an agreement to permit the price to be fixed in the future by the two parties to the contract themselves. In principle it appears to me that they are one and the same thing.

If the wording of the provision was different, such differences of opinions would not occur. Perhaps, if instead of the phrase "The price in a contract of sale may be fixed by the contract, or may...," the provision imposed that "The parties if they so intend may conclude a contract for sale even though the price ...", then the issue would be less problematic.

There have always been debates as to whether the contracts with open essential terms can be held binding (Samek 1970; McLauchlan 1998). Contemporaneous with this case, there was a "strong tradition in the insurance industry to uphold the validity of the future agreements on an essential term" (Ellinghaus 1971). Traditionally, courts believed that this is a fundamental principle of law that 'the court will not make a contract for the parties' (Sutton 1981). However, in cases where the contractors intended to be bound by what they have created and when the court fills the existing incompleteness of such agreement, it is not as if the court is making a contract for the parties (Tarrant, 2006), but it is "merely enabling them to carry out their own intentions" (Howard, 1973-1974).

Contrarily, in Hillas \& Co Ltd v Arcos Ltd [1932] All ER Rep 494, which was decided only two years earlier, having regard to the previous commercial relations between the parties to the contract at hand, the court held that they had already known each other's intention, and no vague feature existed in the contract. In fact, the court first began to move away from a strict, literal interpretation of the terms of a contract; instead, it tried to interpret them in a manner that preserved the parties' bargain. The Court ruled that, rather than to render the contract void, judges may infer terms into it, based on the past dealings of the parties. In this case, it was held that the contractors had fully intended to enter into that commercial agreement. Moreover, judges believed that the parties had decided to be bound by the contract; thus, they stated that whenever possible, the gaps in the contract should be filled by the help of the court and the court should give effect to the agreement (Fridman, 1960). In this case, Lord Wright ([1932] All ER Rep 494, 503-505) stated that: “...the court is to make a contract for the parties, or to go outside the words they have used, except in so far as there are appropriate implications of law, as, for instance, the implication of what is just and reasonable to be ascertained by the court as matter of machinery where the contractual intention is clear but the contract is silent on some detail." He adds that: "...if the construction of the words used may be difficult, that is not a reason for holding them too ambiguous or uncertain to be enforced if the fair meaning of the parties can be extracted."

An agreement for the sale of petrol at a price to be agreed by the parties was held to be a valid and binding contract by the English Court of Appeal in Foley v Classic Coaches Ltd [1934] 2 KB 1. In this case, the intention of the parties to be bound by the contract was enough to convince the court. The agreement was considered as a complete contract in which the parties had a plain intention to be bound by the contract (Chorley, 1935). Previous transactions and continuous conduct of the parties was an additional reason for the court. In this case, Greer L. J. ([1934] 2 KB 1, 12), states that:

The Court is justified in implying that in the absence of agreement as to price a reasonable price must be paid, and if the parties cannot agree as to what is a reasonable price then arbitration must take place. It is quite true that one cannot add to a contract an implied term inconsistent with or which contradicts the express terms of the contract, but in a suitable case one can imply a term, and in my judgment to imply a term in this contract that the price of the petrol supplied by the respondent shall be reasonable is in no way inconsistent with the agreement.

Such opinions are in line with the aforementioned trend in the world to up hold the transactions and agreements between the parties as much as possible. In this case, several years of practicing the same type of contractual relations was an effective factor (Chorley, 1935). However, in Courtney \& Fairburn Ltd v Tolaini Bros (Hotels) Ltd [1975] 1 All ER 716, the same Court refused to recognize a contract in which the price was to be agreed by the parties. In this case, Lord Denning ([1975] 1 All ER 716, p 719-720), states that: "There is no machinery for ascertaining the price except by negotiation. In other words, the price is still to be agreed. Seeing that there is no agreement on so fundamental a matter as the price, there is no contract." Such contradictory opinions are the results of unclear and incomplete rules. The suggestion of the Australian High Court in Hall v Busst ((1960) 104 
CLR 206) was that based on section 8 , only in the executed contracts in which the goods have been delivered and accepted if the parties have been totally quiet about the price, a reasonable price will be determined for the sale. Otherwise, the contract should be void (Atiyah, 2010). The Australian High Court believed that section 8 should not be extended unduly; rather, it should be interpreted narrowly. On the other hand, in Sudbrook Trading Estate Ltd v Eggleton [1983] 1 AC 444, the price was left to be fixed by valuers appointed by the parties. Later, the lessee appointed the valuer while the lessor refused to. Thus, the House of Lords held that the failure of the lessor could not deprive the lessee from his right once he has exercised his option to buy. In fact, in this case the same line of reasoning was also followed.

The SGA 1979 seems to have provided an inadequate and incomprehensive rule that caused continued inconsistency in judicial decisions. The House of Lords in Walford v Miles [1992] 2 AC 128 held that an agreement to negotiate was not enforceable. The Court followed the reasoning that influenced the decision in Courtney \& Fairbairn Ltd v Tolaini Bros (Hotels) Ltd [1975] 1 WLR. Generally, it seems that the international and intra-nation necessities and the interests of the parties require the upholding such contracts. This is based on the needs of today's commercial world, the concept of freedom of contracts, and the fact that in almost all of the open-price sale contracts the parties are aware of the contractual risks and benefits more than any other person. It is undeniable that there is a conflict between the justifications denying the conflict between the articles and comments made by the scholars are insufficient and do not provide a fundamental solution. The conflict should be addressed even if it is an apparent conflict and not a conceptual one.

\subsection{Conflict between Articles 14 (1) and 55 of CISG}

Existence of the interaction between Articles 14 and 55 of the Convention is a considerable problem arising from the CISG. The first issue is whether Article 55 could be applied in disputes caused by the failure to fix a price in a contract for the international sale of goods. This issue itself arises from Article 14, which imposes the condition that an offer must be definite. This means that if the offeror fails to fix the contract price, there is not a valid contract. This approach to the interpretation of Article 14 was adopted in Pratt \& Whitney v. Malev (CLOUT case abstract No. 53). In this case, the seller, an American manufacturer of aircraft engines, made an offer of aircraft engines without specifying their exact price to the buyer, a Hungarian manufacturer of Tupolev aircraft. The court of first instance held that as long as the offer contained provisions for the later determination of the contract price, the offer, and therefore, the contract, was valid.

However, since the provisions of Article 14 (1) had not been followed, and the contract price had not been fixed as required, the Supreme Court, refused to recognize the offer as valid in the above case. Therefore, the Court overturned the decision of the court of first instance and held that no valid contract had been concluded. This decision may be relied upon as an authority for the idea that Articles 55 and 14 should not be read together. Based on this decision, an open-price sale contract is invalid because it fails to meet the requirement of Article 14 (1). Nonetheless, a contrasting decision was reached in a 1997 case (CLOUT case No. 215 [SWITZERLAND Bezirksgericht [District Court] St. Gallen 3 July 1997]) in which the parties had not fixed the purchase price. However, the court resorted to Article 55, and determined the price. Equally, in another case determined in 1999 by way of arbitration, the arbitrators ruled that a "sale without prior fixing of a price is common in international trade, as is shown by the Vienna Convention of 11 April 1980 on the international sale of goods (Article 55) ..." The tribunal, therefore, determined the price of the goods with a view to rendering the contract effective (ICC Arbitration Case No. 9819 of September 1999).

The inconsistency between the above decisions and the associated uncertainty, demonstrate the need for the CISG to be amended. The interplay of Articles 14 and 55 remains a thorny issue that has led to varying and conflicting interpretations. Obviously, this is one disadvantage of the CISG as a codified set of rules; a problem that is exacerbated by the fact that it is meant to be observed in international trade transactions. This makes it even more pertinent for the CISG to be amended in order to remove the defects and difficulties identified, and facilitate more efficient international commerce. It is also believed (Ferrari 1997-1998; Patterson 1986) that to achieve uniformity, one should also notice the foreign case law. The user of the international laws should take the view and interpretation of foreign judicial body's jurisdiction into account as it is highly possible that the same problems and questions have been faced by the foreign courts. Once a question has arisen from one part of the law, and the issue has been successfully, or wrongly, interpreted and practiced by foreign courts, the experience will be one of the best sources for the judge to apply the law in a more correct way. In addition, successful interpretations will lead to further steps towards unification of international law (Ferrari 1997-1998). Accessing the decisions of those courts is not an easy task since they are not prepared and made ready to be used for such a purpose. Moreover, there is the problem of understanding arising from the foreign languages in which the decisions are written (Ferrari, 1997-1998). This is, in fact, one of the reasons why a majority of the decisions 
have referred only to the texts of other decisions coming from the same country, rather than considering the judicial opinions and attitudes of other countries as well. Nevertheless, there are exceptions to this. In Sport d'Hiver di Genevieve Culet $v$ Ets Louys et Fils (Tribunale Cuneo, January 31, 1996, UNILEX), an Italian court referred to two foreign courts in order to decide whether a notice of non-conformity given to the seller 23 days after the goods were delivered was timely or not, and it was found that they did meet the agreed specifications. One of the cases referred to by that court was a Swiss case law on UNCITRAL texts ((CLOUT) abstract no. 56. April 27, 1992) reported in English and the other one in German (case law on UNCITRAL texts (CLOUT) abstract no. 4) on a similar matter. However, this appears to be the only case that has referred to foreign decisions as documents that validate their opinions, at least, as at 1996, even though some institutes have subsequently developed websites and put together collections of the case law from all over the world, as well as an international bibliography on the CISG (Will, 1996).

\section{Third Person Valuation}

In reviewing this part of the law it is worthy to note that in many of the cases, when parties had not agreed on the price, the court preferred to recognize the contract. To respect the will of the parties seems to be a general legal idea in almost all legal systems. To enforce the terms of the contract is almost a world trend and the court normally tries to find a solution in order to maintain the agreement of the parties alive and valid, "even in the absence of agreement on a term which might have been fatal if the whole agreement had remained executory," the trend of many of the courts and scholars is to maintain the contract and recognize it (Atiyah, 2010). It is said that (Atiyah, 2010):

It seems possible therefore, that where parties agree on a sale of goods at prices to be agreed in the future, and the goods are actually delivered and accepted or the agreement is otherwise partly performed, the courts may now be more willing to treat this as a binding contract to sell at a reasonable price, and to provide machinery for the ascertainment of such reasonable prices, even in the absence of a provision such as an arbitration clause by which this could be done under the contract itself.

Based on the above legal facts, the provision of section 9 (1) of the SGA seems unjustifiable. To donate the power to invalidate a contract that has been validly concluded between the parties to a third party seems to be a rule that is not in harmony with any of the other legal rules, principles and aims. According to section 9 (1), "where there is an agreement to sell goods on the terms that the price is to be fixed by the valuation of a third party, and he cannot or does not make the valuation (emphasis added), the agreement is avoided; ...". Although in following, the provision imposes that: "...but if the goods or any part of them have been delivered to and appropriated by the buyer he must pay a reasonable price for them,..." yet, it does not ameliorate the potentially detrimental effect of section 9(1) that weakens the parties to the contract and gives the power of its termination to a third party.

Conversely, in CISG there is no specific reference to price determination by a third party. This issue is considered simply as one of the different methods of determination of the price that the parties may agree on. Thus, if it became impossible to fix the price through the valuation of a third person, the considered price in Article 55 will be imposed.

\section{Impossibility of Price Fixation Due to Fault of One Party}

Although the SGA 1979 has considered the matter of fault of one party, it has however imposed no rule to govern and clarify the situation of the contract following the fault of that party and the impossibility of specifying the price through the agreed method. The impact of the fault of one of the parties on the continuity of the contract itself is the missing element in section 9(1). Instead, the section provides that, "where the third party is prevented from making the valuation by the fault of the seller or buyer, the party not at fault may maintain an action for damages against the party at fault." It should be mentioned that the possibility of maintaining an action for damages against the party at fault is a general matter that can be followed by the party not at fault at any situation. The provision that ought to have been made in this regard is whether the fault of one party will have the effect of cancelling the contract, or a reasonable price will have to be determined, or any other suggestion that clarifies the future position of the contract. The right to claim for damages is another issue altogether. The issue of the validity and enforceability of the contract and the possible options that the party not at fault may have are the missing issues in this part of section 9 and needs to be addressed. There is also another question that arises from this provision. Why has the section only considered the situation in which the determination of the price by a third person has become impossible due to the fault of one party? Why have other methods not been considered? For example, what happens when other methods of price determination are agreed upon but it becomes impossible to fix the price through such agreed methods due to the fault of one party. The CISG has not 
addressed this issue or made any specific rule for it. It is possible that in such a case the domestic law of one country, depending on each particular case, will be enforced in the event where there is no special agreement between the parties.

\section{Reasonable Price}

As aforementioned, United Kingdom practices the common law and writers believe that the concept of open price in the new trading environment is a deviation from the traditional common law since price is a vital feature for all sale contracts (Berry, 2007). Therefore, "under traditional common law, open price term contracts would have been invalidated as 'agreements to agree' and held not to be legally binding" (Berry, 2007).

According to Article 55 of CISG, the proposed price is "the price generally charged at the time of the conclusion of the contract for such goods sold under comparable circumstances in the trade concerned". As can be seen, Article 55 provides some useful guidance by mentioning an alternative mechanism for the determination of the contractual price. Clearly, this is one advantage of this CISG provision. Nonetheless, the same provision on price at the 'time of the conclusion of the contract' can be viewed as a major disadvantage of the provision. The reason why parties to a sale contract may choose to use an open-price term is to avoid any risk caused by price fluctuations. That is the main reason why the parties are usually unwilling to adopt, in their agreement, the price prevailing at the time of the contracts' formation. In fact the transactors prefer not to agree on the price until the goods are ready and are delivered. In that case, whatever the reasonable price of the goods is at the time of their delivery will be the contractual price (Edwards, 1992). Article 55 suggests that the contract price be fixed at the "time of conclusion of the contract." It is hard to accept that the legislators have not considered the situations in which the parties have left the price open with the above mentioned proposes and accordingly, the price of the time of conclusion will not be beneficiary for them. An example for this situation is when "the parties have contracted with the intention to create a long-term contract that recognizes the changes that occur over time to the pricing of the goods" (Mistelis, 2005-2006). To solve this situation, Mistelis suggested that the assumption in Article 55 (time of the conclusion of the contract) "should be treated as a rebuttable presumption". He continues, that "in such situations, it is appropriate for the tribunal or court to consider contract adaptation" (Mistelis, 2005-2006).

Although there are always exceptional cases, generally, if the parties had any intention to adopt the price prevailing at the time of the conclusion of the contract, as their contractual price, they would not leave the price to be open, neither would they not chose a method for its future determination. In such circumstances, it seems questionable why the CISG should propose the price prevailing at the time of the conclusion of the contract as the contract price. Yet, if there are other reasons for the parties to leave the price open rather than the abovementioned situation, and, if the parties intend to deliver the goods and exchange the considerations by the time of the conclusion of the contract, then the price of the time of delivery will still be reasonable as it will be the same price of the 'time of conclusion of the contract'.

The SGA 1979, on the other hand, is silent on the above issue. All it does is to state that the price will be a 'reasonable price.' That Act may, nonetheless, have its advantage in that it provides a brief explanation of the meaning of "reasonable price." It states that, "what is a reasonable price is a question of fact dependent on the circumstances of each particular case (section 8 (3))." In short, this is rather vague and it seems to proper to give a brief description of the suggested price in order to make it clearer what the legislators mean by the provision. What usually comes to mind as a reasonable price is the 'market price'; but does market price always reflect the most fair and "reasonable" price of the goods? To answer this question, reference is made to the following cases (Prosser 1935).

In Kountz v. Kirkpatrick ((1872) 72 Pa. St. 376, 13 Am. Rep. 687), the court said that an unnaturally inflated market price was not always evidence of actual value, and that the jury could determine from the market price before and after the particular date, and from other sources of information, the "actual market value" (Prosser 1932) . In Lovejoy v. Michels ((1891), 88 Mich. 15, 49 N. W. 901, 13 L. R. A. 770) Champlin, J. said that where there was no fair market value of manufactured goods because the market was controlled, evidence to establish reasonable value must necessarily be the cost of production, including the cost of labor and materials, and a reasonable profit. Contrast this case with Murray v. Stanton (1868) 99 Mass. 345, where there was no market for railway bonds because there were no sales, and evidence of the condition of the railroad was held admissible. In addition to this, the parties might agree to choose the market price as the contractual price of the goods without specifying any time and place. In this situation, the court may hold that the market price is the price of the market at the time and place of delivery if no contrary provision or evidence for any contrary intention exists in the contract (Prosser, 1932). 


\section{Conclusion}

The responsibility of regulate the relations among people, groups and countries, and to determine what is correct and just is upon the science of law. Law plays this imperative role via the rules and provisions that are based on principles, goals and soul of law. Law, in fact is a division of social science. This means that the aim of law is to establish such rules that secure justice and order in society and ensure prosperity of the people. Although it is possible that rules on each specific subject differ from one country to another in methods of writing, the attitudes of the legislators and other aspects, however, are factors that are certain and common shared by all of them. In fact, the ultimate aim of law is to maintain public peace. Through legal rules, law aims to govern the relations of people under the authority of law. Law specifies and determines the powers and duties of individuals. It also clarifies their rights, ensure domination of freedom and restrictions in the legal actions.

Rules that handle the subject of the contract of sale of goods, too, should be enacted in a manner that provides for these aims of law. The rules, no matter how and in which country are enacted, have to regularize contract in a way that the parties can reach to the goals of concluding a sale contract. Provisions are not supposed to be drafted in a way that they become the basis of a party's loss. It is also vital to consider the most essential, fundamental and important principle of law that is 'freedom of contract' when legislating such rules. Among contracts with considerations, sale contract is the oldest and most practiced, thus it is vital to consider its related rules as seriously as possible. Hence, to amend insufficient and vague provisions on this legal establishment is necessary and a serious task for the relevant authorities and legislators. Further studies on this issue and a comparative analysis to other similar rules that have accepted open price term will assist the goal of creating a more comprehensive and holistic regulation on this subject. To have a comprehensive and uniformed international law on the one hand, and a harmonized law of sale contract among the countries as much as possible, on the other, will provide a suitable and safe path for the commercial affairs world over. This study, though small, is contended as a necessary step towards world's trade improvement. The table below shows a summary of considerable issues in open price provisions in the SGA 1979 and the CISG.

Table 1. Prevailing issues as to open price term provisions in the SGA 1979 and the CISG

CODIFICATION PREVAILING ISSUES

SGA (1979) 1. Section 8(2) has not considered the situation when the mentioned terms exist in the contract, but, later in practice, they become impossible to be executed

2. The will of a third party can easily make the contract avoided

3. What is provided in section 9(2) concerns other parts of the law; It has not mentioned about what would happen to the contract in case of fault of one party

4. As to the issue of fault of one party, the only considered situation is the party valuation. Other methods have not been included

5. It is a positive point for SGA that has suggested a reasonable price and has described it to some extend

CISG 1. Articles 14 (1) and 55 are in conflict with each other

2. The suggested price is the price of the time of conclusion of the contract not the time of delivery

3. Article 55 has not considered the situation when the mentioned terms exist in the contract, but, later in practice, they become impossible to be executed

4. Nothing is mentioned about the fault of one of the parties

5. Article 55 has not considered the situation when the mentioned terms exist in the contract, but, later in practice, they become impossible to be executed

\section{References}

Atiyah, P. S., Adams, J., \& Macqueen, H. (2010). The Sale of Goods (12th ed.). London: Longman.

Bridge, M. G., Bennett, H., Dawson, F., Lomnicka, E., Miller, C. J., Rawlings, P., ... Treitel, G. (Eds.). (2010). Benjamin's Sale of Goods (8th ed.). London, Sweet \& Maxwell. 
Berry, D. C., Byers, D. M., \& Oates, D. J. (2007). Open Price Agreements: Good Faith Pricing in the Franchise Relationships. Franchise Law Journal, 147, 45-56.

Gabuardi, C. A. (2002-2003). Open Price Terms in the CISG, the UCC and Mexican Commercial Law. In Review of the Convention on Contracts for the International Sale of Goods (CISG) (pp. 23-25). United Kingdom: Kluwer Law International Publication.

Chorley, R. S. T. (1935). Notes. Law Quarterly Review, 51, 277-283.

Edwards, F. R., \& W, M. C. (1992). Futures \& Options (1st ed.). Singapore: McGraw Hill.

Ellinghaus, M. P. (1971). Agreements which Defer "Essential" Terms Part I. Australian Law Journal, 45, 4-7.

Eorsi, G. (1979). Problems of Unifying Law on the Formation of Contracts for the International Sale of Goods. The American Journal of Comparative Law, 27, 311-323. http://dx.doi.org/10.2307/840035

Ferrari, F. (1994). Uniform Interpretation of the 1980 Uniform Sales Law. Georgia Journal of International and Comparative Law, 24(2), 183-228.

Ferrari, F. (1997). General Principles and International Uniform Commercial Law Conventions: A Study of the 1980 Vienna Sales Convention and the 1988 UNIDROIT Conventions. Uniform Law Review, 3(2), 451-473. http://dx.doi.org/10.1093/ulr/2.3.451

Ferrari, F. (1997-1998). CISG case law: A new challenge for interpreters?. Journal of Law \& Commerce, 17(2), 245-261.

Ferrari, F. (1998). Implementations of the Convention on Contracts for the International Sale of Goods (CISG). International Business Law Journal, 7, 835-839.

Fridman, G. L. H. (1960). Construing, without Constructing, a Contract. Law Quarterly Review, 76, 521-580.

Howard, M. (1973). Contracts - Sale - Problems of "Uncertainty". Canadian Bar Review, 51, 668-679.

Mclauchlan, D. (1998). Rethinking Agreements to Agree. New Zealand Universities Law Review, 18, 77-85.

Mistelis, L. (2005-2006). Article 55 CISG: The Unknown Factor. Journal of Law and Commerce, 25(1), 285-298.

Murray, D. E. (1984). The 'Open Price' Sale of Goods Contract in a Worldwide Setting. Franchise Law Journal, 89(9), 491-500.

Murray v. Stanton (1868) 99 Mass. 345.

Patterson, E. H. (1986). United Nations Convention on Contracts for the International Sale of Goods: Unification and the Tension between Compromise and Domination. Stanford Journal of International Law, 22(2), 263-283.

Prosser, W. L. (1932). Open Price in Contracts for the Sale of Goods. Minnesota Law Review, 16(7), 733-790.

Samek, R. A. (1970). The Requirement of Certainty of Terms in the Formation of Contract. Canadian Bar Review, 48, 203-211.

Schwenzer, I., \& Hachem, P. (2009). The CISG-Successes and Pitfalls. The American Journal of Comparative Law, 2(57), 450-478.

Sutton, K. (1981). The Uncertainty of Certainty of Contract. Otago Law Review, 5(1), 11-34.

Tarrant, J. (2006). Preliminary Agreements. University of New England Law Journal, 3, 151-186.

\section{Copyrights}

Copyright for this article is retained by the author(s), with first publication rights granted to the journal.

This is an open-access article distributed under the terms and conditions of the Creative Commons Attribution license (http://creativecommons.org/licenses/by/3.0/). 